\title{
Pengaruh Opini Auditor dan Pertumbuhan Penjualan Perusahaan pada Nilai Perusahaan
}

\author{
Ketut Ita Diantari ${ }^{1}$ \\ I Ketut Suryanawa ${ }^{2}$ \\ ${ }^{1,2}$ Fakultas Ekonomi dan Bisnis Universitas Udayana (Unud), Bali, Indonesia \\ e-mail: itadiantari05@gmail.com
}

\begin{abstract}
ABSTRAK
Penelitian dilakukan untuk mengidentifikasi dan menguji secara empiris pengaruh opini auditor yang merupakan faktor eksternal, dan pertumbuhan penjualan yang merupakan faktor internal perusahaan pada nilai perusahaan. Penelitian dilakukan pada perusahaan sektor industri barang konsumsi periode 2013-2017. Sampel berjumlah 17 perusahaan dipilih secara purposive, sehingga diperoleh 85 pengamatan. Teknik analisis data yang digunakan adalah regresi linier berganda. Hasil penelitian menunjukkan 1) opini auditor tidak berpengaruh pada nilai perusahaan. 2) Pertumbuhan penjualan perusahaan berpengaruh positif pada nilai perusahaan. Berdasarkan hasil yang diperoleh, penelitian memiliki implikasi teoritis yaitu dapat mendukung teori sinyal serta menjadi sumber referensi penelitian lain yang berkaitan dengan nilai perusahaan. Implikasi praktisnya yaitu menjadi bahan pertimbangan bagi investor, kreditur, dan pihak berkepentingan lainnya dalam pengambilan keputusan bisnis.

Kata kunci: Opini auditor, pertumbuhan penjualan perusahaan, nilai perusahaan
\end{abstract}

\begin{abstract}
The study was conducted to identify and test empirically the influence of auditor opinion which is an external factor, and sales growth which is the company's internal factors on the firm's value. The study was conducted on consumer goods industry sector companies for the period 2013-2017. Samples totaling 17 companies was selected purposively, so that 85 observations were obtained. The data analysis technique used is multiple linear regression. The results of the study show 1) the auditor's opinion does not affect the firm's value. 2) Company sales growth has a positive effect on firm's value. Based on the results obtained, the research has theoretical implications, that is, it can support signal theory and become another research reference source related to firm's value. The practical implication is to be considered by investors, creditors, and other interested parties in making business decisions.
\end{abstract}

Keywords: Auditor opinion, company sales growth, firm value

\section{PENDAHULUAN}

Perkembangan dunia bisnis yang semakin pesat membuat perusahaan terus berupaya untuk mengembangkan usaha dan meningkatkan daya saingnya. Hal tersebut dilakukan agar tujuan yang ingin dicapai saat perusahaan didirikan dapat terwujud. Secara umum perusahaan didirikan karena memiliki tujuan untuk 
memperoleh keuntungan atau laba yang maksimal, namun lebih jauh lagi tujuan perusahaan didirikan adalah meningkatkan nilai perusahaan (Gill dan Obradovich, 2012). Nilai perusahaan menjadi sangat berguna karena mampu menarik minat sumber dana potensial seperti investor dan kreditur, oleh karena itu memaksimalkan nilai perusahaan menjadi hal yang sangat penting bagi perusahaan (Suffah dan Riduwan, 2016). Namun, nilai perusahaan manufaktur sektor barang konsumsi yang terdaftar di Bursa Efek Indonesia (BEI) beberapa tahun terakhir menunjukkan trend penurunan. Data terkait penurunan nilai perusahaan manufaktur sektor barang konsumsi dapat dilihat dalam gambar 1 .

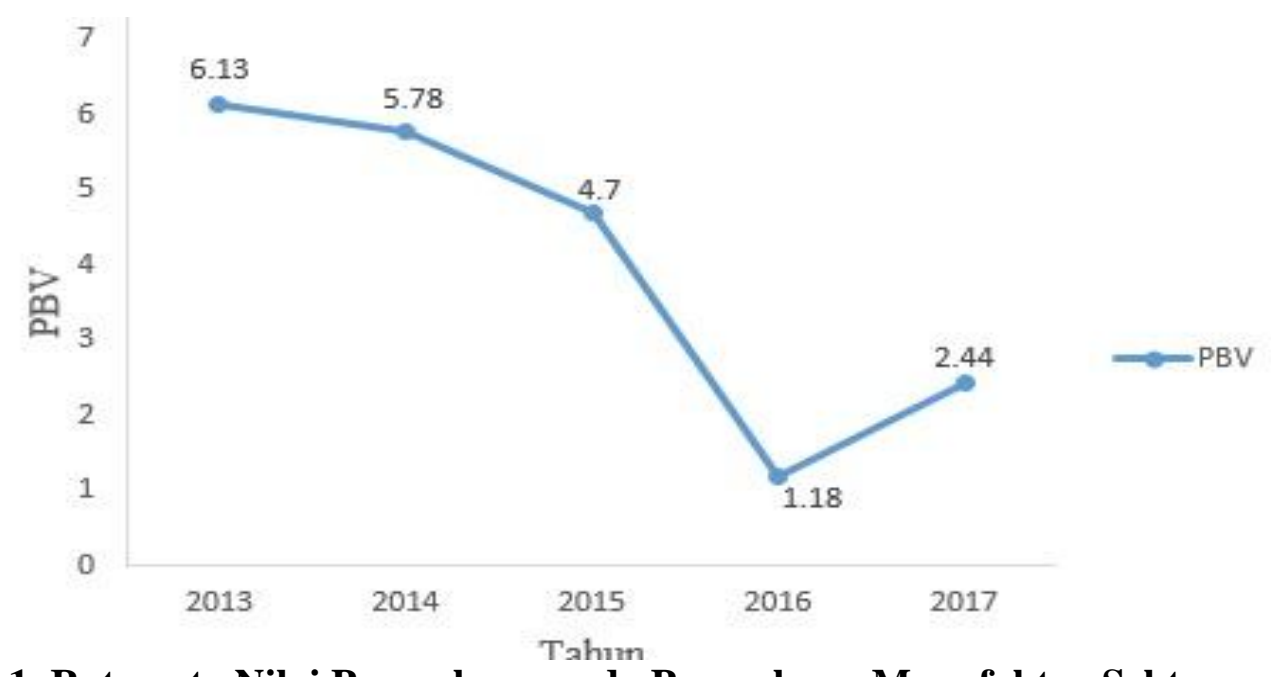

Gambar 1. Rata-rata Nilai Perusahaan pada Perusahaan Manufaktur Sektor Barang Konsumsi yang terdaftar di BEI tahun 2013-2017 Sumber: Data diolah, 2018

Berdasarkan data yang disajikan dalam gambar 1 dapat diketahui nilai perusahaan yang ditunjukkan melalui rasio PBV pada perusahaan manufaktur sektor barang konsumsi yang terdaftar di BEI tahun 2013-2017 cenderung menunjukkan trend penurunan. Penurunan nilai perusahaan pada sektor tersebut terjadi dari tahun 2013 sampai dengan tahun 2016. Penurunan rata-rata nilai perusahaan manufaktur sektor barang konsumsi paling besar terjadi pada tahun 
2016. Rata-rata nilai perusahaan manufaktur tahun 2016 turun sebesar $74,8 \%$ atau turun dari 4,7 pada tahun 2015 menjadi 1,18 pada tahun 2016.

Penurunan nilai perusahaan yang dialami industri manufaktur sesuai dengan fakta bahwa pada tahun tersebut penjualan pada sektor barang konsumsi cenderung turun karena konsumsi rumah tangga terutama konsumsi makanan jadi, minuman, rokok, dan tembakau mengalami penurunan. Penurunan konsumsi pada barang-barang tersebut dikarenakan harga pangan mengalami kenaikan (www.kompas.com, 7 Februari 2016). Fenomena turunnya nilai perusahaan yang telah dijelaskan tentunya membuat investor lebih berhati-hati dalam melakukan investasi pada perusahaan. Investor memerlukan informasi yang akurat agar memperoleh gambaran tentang kondisi perusahaan secara menyeluruh. Susianti dan Yasa (2013) laporan keuangan merupakan salah satu sumber informasi yang dimiliki perusahaan dan digunakan oleh investor untuk melakukan analisis keputusan bisnis.

Salah satu aspek yang menjadi poin penting penilaian stakeholderpada laporan keuangan perusahaan adalah opini audit yang diberikan oleh auditor independen. Deegan dalam Purbawati (2016) opini yang diberikan auditor selaku pihak penilai yang independen atas laporan keuangan perusahaan merupakan alternatif informasi yang dapat dijadikan pedoman bagi pengguna laporan keuangan untuk pengambilan keputusan ekonomi. Purbawati (2016) opini audit atas laporan keuangan menjadi salah satu pertimbangan yang penting bagi investor dalam mengambil keputusan investasi, oleh karena itu auditor sangat diandalkan dalam memberikan informasi yang baik bagi investor. 
Ketut Ita Diantari dan I Ketut Suryanawa. Pengaruh...

Opini wajar tanpa pengecualian merupakan pendapat yang paling diinginkan oleh semua klien, karena opini ini menegaskan dan meyakinkan bahwa laporan keuangan yang disajikan oleh pihak manajemen perusahaan tidak mengandung salah saji material dan sejalan dengan standar akuntansi (Ardiana, 2014). Purbawati (2016) dan Kurniawati (2016) dalam penelitiannya membuktikan bahwa opini wajar tanpa pengecualian yang diberikan auditor dapat meningkatkan nilai perusahaan. Opini wajar tanpa pengecualianakan direspon positif oleh pasar, karena opini tersebut menunjukkan bahwa laporan keuangan perusahaan telah disajikan secara wajar sesuai dengan Prinsip Akuntansi Berterima Umum (PABU).

Faktor lain yang dapat mempengaruhi nilai perusahaan adalah pertumbuhan yang dialami oleh perusahaan.Investor menganggap pertumbuhan perusahaan sebagai tanda bahwa perusahaan memiliki aspek yang menguntungkan dan dapat mempengaruhi peluang investasi (Rasyid, 2015). Teori sinyal menyatakan bahwa informasi baik yang dimiliki perusahaan dapat digunakan sebagai promosi untuk menunjukkan kelebihan perusahaan dibandingkan dengan perusahaan lainnya (Mustafa dan Handayani, 2014). Informasi terkait penjualan perusahaan yang mengalami pertumbuhan merupakan sinyal baik yang dimiliki perusahaan dan dapat disampaikan kepada pihak internal maupun eksternal berkaitan dengan tujuan memaksimalkan nilai perusahaan.

Perusahaan yang memiliki pertumbuhan penjualan positif akan memperoleh penilaian yang positif di mata investor. Peningkatan pertumbuhan penjualan perusahaan yang direspon positif oleh investor dapat berdampak pada 
nilai perusahaan yang juga meningkat. Hal ini dibuktikan dalam penelitian Fista (2017), Sandag (2015), serta Sharon dan Murni (2015) yang memperoleh hasil bahwa pertumbuhan penjualan perusahaan memiliki pengaruh positif pada nilai perusahaan. Hal ini dikarenakan pertumbuhan penjualan perusahaan sangat diharapkan oleh pihak internal maupun eksternal perusahaan, sebab pertumbuhan penjualan menjadi tanda bahwa perusahaan telah mengalami perkembangan. Berbeda dengan penelitian Hansen dan Huniarti (2014) yang memperoleh hasil pertumbuhan penjualan tidak memiliki pengaruh pada nilai perusahaan.

Penelitian ini merupakan pengembangan dari penelitian Mandalika (2016) yang meneliti pengaruh struktur aktiva, struktur modal dan pertumbuhan penjualan terhadap nilai perusahaan sektor otomotif yang terdaftar di BEI. Pengembangan dilakukan karena penelitian Mandalika (2016) hanya meneliti pengaruh faktor-faktor internal perusahaan terhadap nilai perusahaan, sedangkan pada penelitian ini peneliti ingin mengetahui bagaimana faktor eksternal perusahaan jugadapat mempengaruhi nilai perusahaan. Dalam penelitian ini peneliti tidak membahas mengenai variabel struktur aktiva dan struktur modal, namun menambahkan variabel opini auditor. Variabel struktur modal tidak digunakan karena hasil penelitian yang didapatkan sudah konsisten dengan hasil penelitian sebelumnya.

Penelitian Mandalika (2016) menggunakan rasio price book value (PBV) sebagai proksi nilai perusahaan, sedangkan dalam penelitian ini nilai perusahaan diukur menggunakan rasio Tobin's Q. Bella dan Suaryana (2017) Tobin's Q dinilai dapat memberikan informasi paling baik dalam menentukan nilai 
perusahaan sebab rasio ini memasukkan semua unsur hutang, modal saham dan seluruh aset perusahaan. Pengembangan lain terkait dengan perusahaan yang menjadi objek penelitian, yaitu perusahaan manufaktur sektor barang konsumsi. Dipilihnya satu kelompok industri yaitu industri manufaktur dimaksudkan untuk menghindari bias yang disebabkan oleh efek industri (industry effect). Wulandari dan Ramantha (2016) efek industri adalahrisiko industri yang berbeda antara sektor industri yang satu dengan yang lain. Pemilihan sektor barang konsumsi didasari alasan terkait dengan fenomena yang telah dijelaskan, bahwa sektor ini mengalami penurunan nilai perusahaan beberapa tahun terakhir.

Penelitian dilakukan untuk mengetahui pengaruh opini auditor dan pertumbuhan penjualan perusahaan pada nilai perusahaan. Hasil penelitian diharapkan dapat memberi bukti empiris teori-teori yang digunakan seperti teori sinyal dan keagenan. Manfaat lain yang diharapkan adalah dapat memberikan kontribusi, sebagai tambahan refrensi dan bahan pengembangan penelitian selanjutnya mengenai pengaruh opini auditor dan pertumbuhan penjualan perusahaan pada nilai perusahaan. Informasi yang berhasil dikumpulkanpada penelitian ini juga diharapkan mampu menjadi informasi tambahan bagi pihak berkepentingan dalam melakukan keputusan bisnis atau keputusan investasi pada perusahaan.

Teori sinyal menunjukkan bagaimana asimetri informasi dapat dikurangi oleh pihak yang lebih banyak memiliki informasi dengan mengirimkan sinyal kepada pihak lain (Moris, 1987). Teori sinyal menjelaskan perilaku dari pihak yang mempunyai akses pada informasi (individu atau organisasi), tentang 
bagaimana mengomunikasikan informasi tersebut dan bagaimana pihak yang berkepentingan dapat menafsirkan informasi yang diberikan (Spence, 1973). Perusahaan yang berkualitas baik sengaja memberikan sinyal pada pasar, dengan demikian pasar diharapkan dapat membedakan perusahaan yang berkualitas baik dan yang berkualitas buruk (Birjandi dan Hakemi, 2015).

Manajemen selalu berusaha untuk mengungkapkan informasi privat yang menurut pertimbangan perusahaan sangat diminati investor dan pemegang saham, khususnya jika informasi yang diungkapkan perusahaan merupakan berita baik (good news). Hal tersebut dilakukan perusahaan agar pasar dapat mengetahui bahwa perusahaan memiliki kinerja dan prospek yang baik jika dibandingkan dengan perusahaan lain. Penyampaian informasi tersebut juga dilakukan karena memiliki tujuan untuk mengurangi asimetri informasi antara pasar dengan perusahaan (Spence, 1973).

Teori keagenan adalah teori yang menjelaskan hubungan atau kontrak kerja antara prinsipal selaku pemilik modal denganagen selaku pengelola modal atau manajemen perusahaan. Dalam kontrak kerjanya, prinsipal akan mempekerjakan agen agar melakukan tugas untuk kepentingan prinsipal, termasuk pendelegasian otorisasi pengambilan keputusan dari prinsipal kepada agen (Jensen dan Meckling, 1976). Kontrak atau hubungan kerja antara prinsipal dan agen dapat mengarah pada kondisi ketidakseimbangan informasi (asymmetrical information) yang dapat menyebabkan masalah agensi. Masalah agensi dapat terjadi karena agen berada pada posisi yang memiliki informasi lebih banyak tentang perusahaan dibandingkan dengan prinsipal(Putri dan Dwija, 2016). 
Dengan asumsi bahwa individu bertindak untuk memaksimalkan kepentingan diri sendiri, maka melalui informasi asimetri yang dimiliki akan mendorong agenuntuk menyembunyikan beberapa informasi yang tidak diketahui principal (Jensen dan Meckling, 1976). Meskipun manajer dan pemegang saham memiliki tujuan untuk memaksimalkan kekayaan perusahaan, tetapi dalam pelaksanaannya kepentingan kedua belah pihak dapat berbeda. Investor berkeinginan untuk meningkatkan kekayaannya dalam bentuk pembagian dividen, sedangkan manajer perusahaan berkepentingan untuk meningkatkan kesejahteraannya salah satunya dalam bentuk bonus (Farooq dan Ahmed, 2015).

Dalam teori agensi, auditor independen menjadi pihak yang dianggap mampu menjembatani perbedaan kepentingan antara pihak prinsipaldengan pihak agendalam mengelola perusahaan. Untuk meyakinkan bahwa manajemen bekerja secara baik dan benardemi kepentingan pemilik perusahaan dan meminimalkan masalah keagenan, pemilik perusahaan menggunakan auditor independen untuk melakukan audit atas laporan keuangan yang dibuat oleh manajemen perusahaan (Moazedi dan Khansalar, 2016). Konflik-konflik agensi dapat dikurangi ketika auditor eksternal memiliki independensi yang cukup untuk menghasilkan informasi yang mencerminkan situasi keuangan yang sebenarnya dari perusahaan klien (Martinez, 2014). Auditor eksternal sebagai perwakilan independen dari prinsipal akan melakukan proses audit dan memberikan opininya untuk menilai kewajaran laporan keuangan yang disajikan perusahaan klien (Pakdaman, 2018). Opini wajar tanpa pengecualian yang diperoleh perusahaan dapat meningkatkan kepercayaan pemilik atau pihak lain yang berkepentingan pada perusahaan 
sehingga mampu meningkatkan nilai perusahaan.Berdasarkan teori, riset dan logika yang dikembangkan maka hipotesis yang dirumuskan sebagai berikut:

$\mathrm{H}_{1}$ : Opini auditor berpengaruh positif pada nilai perusahaan.

$\mathrm{H}_{2}$ : Pertumbuhan penjualan perusahaan berpengaruh positif pada nilai perusahaan.

\section{METODE PENELITIAN}

Pendekatan yang digunakan dalam penelitian adalah asosiatif dengan hubungan kausal. Penelitian ini membahas pengaruh opini auditor dan pertumbuhan penjualan perusahaan pada nilai perusahaan.Penelitian ini berlokasi di Bursa Efek Indonesia. Penelitian dilakukan dengan mengakses data-data sekunder berupa laporan keuangan tahunan seluruh perusahaan manufaktur sektor barang konsumsi yang terdaftar di BEI periode 2013-2017. Data-data yang diperlukan tersebut diakses melalui situs website www.idx.co.id dan dari web yang dimiliki masingmasing perusahaan. Variabel terikat dalam penelitian ini adalah nilai perusahaan. Variabel independen dalam penelitian ini adalah opini auditor dan pertumbuhan penjualan perusahaan.

Nilai perusahaan merupakan persepsi investor terhadap tingkat keberhasilan perusahaan dalam mengelola sumber daya. Nilai perusahaan yang tinggi dapat mempengaruhi persepsi calon investor agar lebih percaya pada prospek perusahaan (Purwohandoko, 2017). Pada penelitian ini nilai perusahaan diproksikan dengan Tobin's Q. Tobin's Q dinilai dapat memberikan informasi paling baik dalam mengukur nilai pasar perusahaan karena rasio ini memasukkan semua unsur hutang, modal saham perusahaan dan seluruh aset perusahaan (Bella 
dan Suaryana, 2017). Aset perusahaan yang dimasukkan dalam perhitungan Tobin's Q menunjukkan bahwa perusahaan tidak hanya terfokus pada satu tipe investor yaitu investor dalam bentuk saham, namun perusahaan juga terfokus pada kreditur (Antwi dan Mills, 2012).

Nilai Tobin's Q yang berada di bawah 1 menunjukkan bahwa nilai pasar perusahaan lebih kecil dari nilai ganti aset perusahaan. Pasar menilai investasi dalam perusahaan belumlah menarik. Nilai Tobin's Q berada di atas 1 berarti nilai ganti aset perusahaan lebih kecil dari nilai pasar perusahaan dan akan menciptakan investasi baru (Herawaty, 2008). Perhitungan Tobin's Q mengacu pada rumus Chung dan Pruitt (1994). Selanjutnya rumus disesuaikan dengan perusahaan di Bursa Efek Indonesia dengan tidak menyertakan liquidating value of the firm's outstanding preferred stock (saham preferen) karena pada umumnya perusahaan di Bursa Efek Indonesia tidak menerbitkan saham preferen (Gherghina, 2015). Tobin's Q dihitung dengan rumus sebagai berikut:

Tobin's Q $=\frac{\text { MVE }+ \text { DEBT }}{\text { TA }}$

Keterangan:

MVE = Market Value of Equity (jumlah saham beredar dikali closing price)

DEBT $=$ Total kewajiban perusahaan

TA $=$ Total aset perusahaan

Pengukuran variabel opini auditor menggunakan variabel dummy, berdasarkan opini yang diterima perusahaan pada laporan keuangan yang telah diaudit. Angka 1 diberikan untuk perusahaan yang laporan keuangannya memperoleh opini wajar tanpa pengecualian (unqualified opinion) dan kategori 0 
diberikan untuk perusahaan yang laporan keuangannya memperoleh opini selain wajar tanpa pengecualian (selain unqualified opinion). Skala data yang digunakan adalah skala data nominal.

Pertumbuhan penjualan (growth of sales) adalah kenaikan jumlah penjualan dari tahun ke tahun atau dari waktu ke waktu. Pertumbuhan penjualan mencerminkan keberhasilan investasi pada periode masa lalu dan dapat dijadikan sebagai prediksi pertumbuhan di masa yang akan datang (Carnevela, 2017). Secara matematis, pertumbuhan penjualan perusahaan dapat dirumuskan sebagai berikut:

Pertumbuhan Penjualan $=\frac{\text { Penjualan } \mathrm{i}, \mathrm{t}-\text { Penjualan } \mathrm{i}, \mathrm{t}-1}{\text { Penjualan } \mathrm{i}, \mathrm{t}-1}$

Keterangan untuk rumus pertumbuhan penjualan perusahaan:

Penjualan $_{\mathrm{i}, \mathrm{t}} \quad=\quad$ Total penjualan perusahaan $\mathrm{i}$ pada tahun $\mathrm{t}$

Penjualan $_{\mathrm{i}, \mathrm{t}-1} \quad=\quad$ Total penjualan perusahaan $\mathrm{i}$ pada tahun $\mathrm{t}-1$

Kriteria penentuan sampel pada penelitian ini yaitu, 1) perusahaan manufaktur sektor barang konsumsi yang listing di BEI dan secara berturut-turut mempublikasikan laporan keuangan tahunan pada periode pengamatan tahun 2013 sampai 2017. 2) Laporan keuangan tahunan yang diterbitkan perusahaan menyajikan data yang diperlukan secara lengkap untuk melakukan perhitungan terkait dengan variabel yang digunakan dalam penelitian.Teknik analisis data yang digunakan dalam penelitian ini adalah teknik analisis regresi linier berganda dengan menggunakan SPSS. Tahapan analisis data yang dilakukan yaitu uji asumsi klasik, analasis regresi linier berganda, koefisien determinasi $\left(R^{2}\right)$, uji kelayakan model (Uji F), dan uji hipotesis (Uji t). 
Ketut Ita Diantari dan I Ketut Suryanawa. Pengaruh...

\section{HASIL DAN PEMBAHASAN}

Perusahaan manufaktur sektor barang konsumsi yang terdaftar di BEI berjumlah 46 perusahaan. Terdapat 13 perusahaan yang tidak memenuhi kriteria penentuan sampel pertama, yaitu tidak menerbitkan laporan keuangan tahunan secara berturut-turut pada periode pengamatan tahun 2013 sampai 2017. Perusahaan yang tidak memenuhi kriteria pertama penentuan sampel tersebut dikeluarkan dari sampel penelitian, sebab pada penelitian ini terdapat variabel pertumbuhan penjualan. Perhitungan variabel pertumbuhan penjualan memerlukan data penjualan secara berturut-turut selama periode pengamatan. Nilai dari variabel pertumbuhan penjualan tidak dapat ditentukan jika perusahaan tidak menerbitkan laporan keuangan secara berturut-turut. Oleh karena itu, 13 perusahaan yang tidak mempublikasikan laporan keuangan tahunan secara berturut-turut pada periode pengamatan harus dikeluarkan dari sampel penelitian.

Populasi penelitian berjumlah 46 perusahaan, kemudian dikurangi dengan 13 perusahaan yang tidak memenuhi kriteria penetuan sampel, sehingga menghasilkan jumlah sampel penelitian sebanyak 33 perusahaan. Setelah diperoleh 33 perusahaan sampel, penelitian dilanjutkan dengan melakukan pengolahan data. Berdasarkan pengolahan data yang dilakukan yaitu uji normalitas, didapatkan 16 perusahaan yang memiliki data outlier. Data outlier adalah data dengan karakteristik unik yang memiliki nilai sangat berbeda dan jauh dari observasi-observasi lainnya. Data outlier muncul dalam bentuk nilai ekstrim untuk sebuah variabel tunggal atau variabel kombinasi (Ghozali, 2016: 41). Data outlier pada penelitian ini menyebabkan residual data perusahaan sampel tidak 
terdistribusi secara normal, sehingga perusahan dengan data outlier dikeluarkan dari sampel penelitian.

Perusahaan yang memiliki data outlier dan dikeluarkan dari sampel penelitian adalah PT Tri Bayan Tirta Tbk, PT Wilmar Cahaya Indonesia Tbk, PT Delta Djakarta Tbk, PT Multi Bintang Indonesia Tbk, PT Prasidha Aneka Niaga Tbk, PT Nippon Indosari Corporindo Tbk, PT Sekar Bumi Tbk, PT Wismilak Inti Makmur Tbk, PT Indofarma Tbk, PT Pyridam Farma Tbk, PT Industri Jamu dan Farmasi Sido Muncul Tbk, PT Akasha Wira International Tbk, PT Martina Bento Tbk, PT Mustika Ratu Tbk, PT Kedaung Indah Can Tbk, dan PT Langgeng Makmur Industry Tbk. Jumlah sampel akhir setelah dikurangi data outlier pada penelitian adalah 17 perusahaan, dengan total pengamatan dari tahun 2013 sampai dengan tahun 2017 yaitu 85 pengamatan.

\section{Tabel 1.}

Hasil Statistik Deskriptif

\begin{tabular}{lccccc}
\hline & N & Minimum & Maximum & Mean & $\begin{array}{c}\text { Std. } \\
\text { Deviation }\end{array}$ \\
\hline & 85 & 0 & 1 & 0,86 & 0,350 \\
$\begin{array}{l}\text { Pertumbuhan } \\
\begin{array}{l}\text { Penjualan } \\
\text { Nilai }\end{array}\end{array}$ & 85 & 0,0019 & 0,4765 & 0,1198 & 0,0864 \\
$\begin{array}{l}\text { Perusahaan } \\
\text { Sumber: Data diolah, } 2018\end{array}$ & 85 & 0,6843 & 23,2858 & 4,1994 & 4,5863 \\
\hline
\end{tabular}

Tabel 1 menyajikan hasil terkait analisis deskriptif penelitian. Berdasarkan data yang disajikan dalam tabel 1 dapat diketahui bahwa total pengamatan $(\mathrm{N})$ berjumlah 85 . Jumlah pengamatan sebanyak 85 diperoleh karena, penelitian dilakukan pada 17 perusahaan manufaktur sektor barang konsumsi dengan periode pengamatan selama lima tahun, yaitu tahun 2013 sampai dengan tahun 2017. 
Variabel opini auditor diukur dengan dummy, nilai 1 diberikan untuk perusahaan manufaktur sektor barang konsumsi yang terdafatar di BEI periode 2013-2017 yang laporan keuangannya memperoleh opini wajar tanpa pengecualian, sedangkan nilai 0 diberikan untuk perusahaan yang laporan keuangannya memperoleh opini selain wajar tanpa pengecualian. Hasil analisis deskriptif menunjukkan nilai minimum dari variabel opini auditor adalah 0 . Nilai minimum tersebut memiliki makna bahwa, terdapat beberapa perusahaan yang memperoleh opini selain wajar tanpa pengecualian pada laporan keuangan yang diaudit oleh auditor independen. Dalam penelitian ini nilai 0 menunjukkan bahwa, laporan keuangan tahunan dari beberapa perusahaan sampel memperoleh jenis opini yaitu wajar tanpa pengecualian dengan paragraf penjelas.

Nilai maksimum variabel opini auditor dalam penelitian ini adalah 1 . Nilai tersebut berarti berdasarkan proses audit yang dilakukan, auditor independen memberikan opini wajar tanpa pengecualian pada laporan keuangan yang disajikan oleh perusahaan klien. Variabel opini auditor memiliki nilai rata-rata 0,86. Hal ini menunjukkan 8 6persen dari 85 total pengamatan atau samadengan 73 pengamatan, laporan keuangan perusahaan sampel telah disusun dalam semua hal yang material dan sesuai dengan kerangka pelaporan keuangan yang berlaku. Nilai standar deviasi dari variabel opini auditor yaitu 0,350 . Nilai standar deviasi tersebut lebih rendah dari nilai rata-rata, hal ini menandakan bahwa sebaran data variabel opini auditor sudah merata atau perbedaan data satu dengan data yang lainnya tidak tergolong tinggi. 
Hasil analisis deskriptif untuk variabel pertumbuhan penjualan perusahaan menunjukkan bahwa nilai minimumnya adalah 0,0019 dan nilai maksimumnya sebesar 0,4765. Nilai minimum memiliki arti bahwa, pertumbuhan penjualan dari 17 perusahaan yang menjadi sampel penelitian selama periode pengamatan paling rendah adalah 0,0019 atau 0,19 persen yang diperoleh oleh PT Darya Varia Laboratoria Tbk (DVLA) pada tahun 2014. Hal ini berarti penjualan DVLA pada tahun 2014 meningkat sebesar 0,19 persen dibandingkan dengan penjualan di tahun 2013, atau dapat dimisalkan setiap Rp100 penjualan DVLA pada tahun 2013 meningkat menjadi Rp.100,19 di tahun 2014. Nilai minimum dari variabel pertumbuhan penjualan masih menunjukkan arah positif, sehingga dapat disimpulkan bahwa penjualan seluruh perusahaan yang menjadi sampel penelitian terus mengalami peningkatan setiap tahunnya.

Nilai maksimum memiliki arti bahwa, pertumbuhan penjualan dari 17 perusahaan yang menjadi sampel penelitian selama periode pengamatan paling tinggi adalah 0,4765 atau 47,65 persen yang diperoleh oleh PT Tiga Pilar Sejahtera Food Tbk (AISA) di tahun 2013. Hal ini berarti penjualan AISA pada tahun 2013 meningkat sebesar 47,65 persen dibandingkan dengan penjualan di tahun 2012, atau dapat dimisalkan setiap Rp100 penjualan AISA pada tahun 2012 mengalami peningkatan menjadi Rp.147,65 di tahun 2013. Variabel pertumbuhan penjualan memiliki nilai rata-rata 0,1198 . Nilai rata-rata sebesar 0,1198 menandakan bahwa sebagian besar penjualan perusahaan sampel mengalami peningkatan 11,98 persen jika dibandingkan penjualan tahun sebelumnya. Hal ini juga dapat dimisalkan bahwa, setiap Rp100 penjualan sebagian besar perusahaan 
sampel tahun sebelumnya, meningkat menjadi Rp111,98 pada tahun berikutnya. Nilai standar deviasi dari pertumbuhan penjualan sebesar 0,0864 nilai ini lebih rendah dari nilai rata-rata, yang berarti sebaran data variabel pertumbuhan penjualan perusahaan telah merata.

Hasil analisis deskriptif menunjukkan nilai minimum dari variabel nilai perusahaan yang diproksikan dengan Tobin's Q adalah 0,6843 dan nilai maksimumnya sebesar 23,2858. Nilai minimum memiliki arti bahwa, nilai perusahaan dari 17 perusahaan yang menjadi sampel penelitian selama periode pengamatan paling rendah adalah 0,6843 yang dimiliki PT Indofood CBP Sukses Makmur Tbk (ICBP) pada tahun 2017. Nilai minimum Tobin's Q sebesar 0,6843 memiliki arti bahwa, nilai pasar dari ICBP pada tahun 2017 adalah 0,6843kali nilai ganti aset perusahaannya. Nilai maksimum memiliki arti bahwa, nilai perusahaan dari 17 perusahaan yang menjadi sampel penelitian selama periode pengamatan paling tinggi adalah 23,2858 yang diperoleh oleh PT Unilever Indonesia Tbk (UNVR) pada tahun 2017. Nilai Tobin's Q sebesar 23,2858 memiliki arti bahwa, nilai pasar dari UNVR pada tahun 2017 adalah 23,2858kali nilai ganti aset perusahaannya. Variabel nilai perusahaan yang diukur dengan Tobin's Q memiliki nilai rata-rata 4,1994.

Nilai rata-rata sebesar 4,1994 menunjukkan bahwa, nilai pasar sebagian besar perusahaan manufaktur sektor barang konsumsi yang menjadi sampel penelitian adalah 4,1994kali nilai ganti aset perusahaannya. Secara rata-rata sebagian besar perusahaan yang menjadi sampel penelitian menunjukkan rasio nilai perusahaan di atas 1. Nilai ini mengindikasikan bahwa, investasi yang 
dilakukan perusahaan telah menghasilkan profit atau dengan kata lain investasi yang dikeluarkan lebih kecil dari hasil yang diperoleh, tentunya hal ini dapat memicu ransangan tehadap investasi baru. Standar deviasi dari Tobin's Q sebesar 4,5863 menunjukkan bahwa terjadi perbedaan nilai perusahaan yang diteliti dengan nilai rata-ratanya sebesar 4,5863.

Tabel 2.

Hasil Uji Normalitas sebelum Pengamatan dikurangi DataOutlier

\begin{tabular}{lc}
\hline & Unstandardized Residual \\
\hline $\mathrm{N}$ & 165 \\
Kolmogorov-Smirnov Z & 4,725 \\
Asymp. Sig (2-tailed) & 0,000 \\
\hline Sumber: Dat diolah, 2018
\end{tabular}

Sumber: Data diolah, 2018

Berdasarkan data yang disajikan dalam tabel 2 dapat diketahui bahwa nilai Asymp. Sig (2-tailed) adalah 0,000. Nilai tersebut kurang dari tingkat signifikansi yang digunakan yaitu 0,05 . Hal tersebut menunjukkan bahwa residual data pada penelitian tidak berdistribusi normal. Cara yang digunakan untuk mengatasi permasalahan tersebut adalah mengeluarkan beberapa perusahaan yang memiliki data outlier dari sampel penelitian. Pengujian normalitas dilakukan kembali setelah beberapa perusahaan yang memiliki data outlier dikeluarkan dari sampel. Hasil pengujian dapat dilihat pada tabel 3.

Tabel 3.

Hasil Uji Normalitas setelah Pengamatan dikurangi Data Outlier

\begin{tabular}{lc}
\hline & Unstandardized Residual \\
\hline $\mathrm{N}$ & 85 \\
Kolmogorov-Smirnov Z & 1,244 \\
Asymp. Sig (2-tailed) & 0,091 \\
\hline
\end{tabular}

Sumber: Data diolah, 2018

Tabel 3 menyajikan data terkait dengan hasil uji normalitas setelah pengamatan dikurangi perusahaan yang memiliki data outlier, dari tabel tersebut dapat diketahui bahwa nilai Asymp. Sig (2-tailed) adalah 0,091. Nilai tersebut 
lebih dari tingkat signifikansi yang digunakan yaitu 0,05 . Hal ini menunjukkan bahwa residual data dalam penelitian telah terdistribusi secara normal.

Tabel 4.

Hasil Uji Multikolinearitas

\begin{tabular}{|c|c|c|}
\hline \multirow[t]{2}{*}{ Variabel } & \multicolumn{2}{|c|}{ Colinearity Statistics } \\
\hline & Tolerance & VIF \\
\hline Opini Auditor & 0,998 & 1,002 \\
\hline Pertumbuhan Penjualan & 0,998 & 1,002 \\
\hline
\end{tabular}

Berdasarkan data yang disajikan dalam tabel 4 dapat diketahui bahwa nilai tolerance variabel opini auditor adalah 0,998 atau 99,8 persen dan nilai VIF 1,002. Nilai tolerance variabel pertumbuhan penjualan perusahaan adalah 0,998 atau 99,8 persen dan nilai VIF 1,002. Berdasarkan nilai tersebut dapat diketahui nilai tolerance masing-masing variabel bebas lebih dari 10persen dan nilai VIF kurang dari 10, maka dapat disimpulkan bahwa model regresi yang digunakan bebas dari masalah multikolinearitas.

Tabel 5. Hasil Uji Heteroskedastisitas

\begin{tabular}{lcc}
\hline Variabel & $\mathbf{t}$ & Sig. \\
\hline Opini Auditor & $-0,458$ & 0,648 \\
Pertumbuhan Penjualan & 1,248 & 0,215
\end{tabular}

Sumber: Data diolah, 2018

Tabel 5 menyajikan data terkait hasil uji heteroskedastisitas, dari tabel tersebut dapat diketahui bahwa nilai signifikansi variabel opini auditor adalah 0,648 atau 64,8 persen dan nilai signifikansi variabel pertumbuhan penjualan perusahaan adalah 0,215 atau 21,5 persen. Berdasarkan nilai tersebut dapat diketahui bahwa seluruh variabel bebas dalam model regresi ini memiliki nilai signifikansi lebih dari $\alpha$ yaitu 5 persen, sehingga dapat disimpulkan bahwa pada model regresi tidak terjadi gejala heterokedastisitas. 
Tabel 6.

Hasil Uji Autokorelasi

\begin{tabular}{lccccc}
\hline Model & R & R Square & $\begin{array}{c}\text { Adjusted } \\
\text { R Square }\end{array}$ & $\begin{array}{c}\text { Std. Error Of } \\
\text { the Estimate }\end{array}$ & $\begin{array}{c}\text { Durbin- } \\
\text { Watson }\end{array}$ \\
\hline 1 & 0,495 & 0,245 & 0,227 & 1,999651 & 2,255 \\
\hline Sumber: Data diolah, 2018 & & & &
\end{tabular}

Berdasarkan data yang disajikan dalam tabel 6 dapat diketahui bahwa nilai Durbin-Watson adalah 2,255. Penelitian ini menggunakan level of significant 0,05 dengan jumlah pengamatan $(\mathrm{N})$ yaitu 85 , dan jumlah variabel bebas $\left(\mathrm{k}^{\prime}\right)$ adalah 2 , sehingga sesuai dengan tabel pada lampiran 13 nilai $d_{L}=1,5995$ nilai $d_{U}=1,6957$ dan nilai $4-\mathrm{d}_{\mathrm{U}}=2,3043$. Nilai Durbin-Watson sebesar 2,255 berada diantara nilai $\mathrm{d}_{\mathrm{U}}=1,6975$ dan nilai $4-\mathrm{d}_{\mathrm{U}}=2,3043$ atau $(1,6957<2,255<2,3043)$ ini berarti pada model regresi yang digunakan tidak terdapat gejala autokorelasi.

Tabel 7.

Hasil Analisis Regresi Linier Berganda

\begin{tabular}{|c|c|c|c|}
\hline \multirow[t]{2}{*}{ Model } & \multicolumn{2}{|c|}{ Unstandardized Coefficients } & \multirow[t]{2}{*}{ Sig } \\
\hline & B & Std. Error & \\
\hline 1 Constant & 1,190 & 0,688 & 0,087 \\
\hline Opini Auditor & 1,152 & 0,624 & 0,068 \\
\hline Pertumbuhan Penjualan & 13,765 & 2,807 & 0,000 \\
\hline
\end{tabular}

Sumber:Data diolah, 2018

Berdasarkan data yang disajikan dalam tabel 7 dapat diketahui nilai konstanta $(\alpha)$ adalah 1,190 nilai tersebut memiliki arti bahwa secara statistik hasil regresi menunjukkan apabila nilai opini auditor $\left(\mathrm{X}_{1}\right)$ dan pertumbuhan penjualan perusahaan $\left(\mathrm{X}_{2}\right)$ dianggap konstan (nol), maka nilai Tobin's $\mathrm{Q}(\mathrm{Y})$ akan naik sebesar 1,190 satuan.Nilai $\beta_{1}$ yaitu 1,152 menunjukkan bahwa terdapat pengaruh positif antara opini auditor $\left(\mathrm{X}_{1}\right)$ dengan Tobin's $\mathrm{Q}(\mathrm{Y})$ sebesar 1,152. Nilai tersebut memiliki arti bahwa jika opini auditor $\left(\mathrm{X}_{1}\right)$ naik sebesar 1 satuan dengan asumsi variabel lain dianggap konstan (nol), maka Tobin's Q (Y) diharapkan 
meningkat sebesar 1,152 satuan. Nilai $\beta_{2}$ yaitu 13,765 menunjukkan bahwa terdapat pengaruh positif antara pertumbuhan penjualan perusahaan $\left(\mathrm{X}_{2}\right)$ dengan Tobin's Q (Y) sebesar 13,765. Nilai tersebut memiliki arti bahwa jika pertumbuhan penjualan perusahaan $\left(\mathrm{X}_{2}\right)$ naik sebesar 1 satuan dengan asumsi variabel lain dianggap konstan (nol), maka Tobin's Q (Y) diharapkan meningkat sebesar 13,765 satuan.

Tabel 8.

Hasil Uji Koefisien Determinasi

\begin{tabular}{lcccc}
\hline Model & R & R Square & $\begin{array}{c}\text { Adjusted R } \\
\text { Square }\end{array}$ & $\begin{array}{c}\text { Std. Error Of the } \\
\text { Estimate }\end{array}$ \\
\hline 1 & 0,495 & 0,245 & 0,227 & 1,999651 \\
\hline
\end{tabular}

Sumber: Data diolah, 2018

Berdasarkan data yang disajikan dalam tabel 8 dapat diketahui bahwa nilai koefisien determinasi yang dilihat dari adjusted $R$ square adalah 0,227 atau 22,7 persen. Nilai koefisien determinasi tersebut memiliki arti bahwa sebesar 22,7 persen variasi variabel nilai perusahaan (Y) yang diproksikan dengan Tobin's Q dapat dijelaskan oleh variabel opini auditor dan pertumbuhan penjualan perusahaan, sedangkan sisanya sebesar 77,3 persen dipengaruhi oleh variabel lain yang tidak digunakan dalam model regresi pada penelitian ini.

Tabel 9.

Hasil Uji Kelayakan Model (Uji F)

\begin{tabular}{llcc}
\hline Model & F & Sig. \\
\hline 1 & Regression & 13,337 & 0,000 \\
& Residual & & \\
$\quad$ Total & & \\
\hline Sumber: & Data diolah, 2018 & &
\end{tabular}

Berdasarkan data yang disajikan dalam tabel 9 dapat diketahui bahwa nilai F hitung adalah 13,337 dengan signifikansi 0,000 kurang dari 0,05. Hal tersebut menunjukkan bahwa variabel opini auditor dan pertumbuhan penjualan 
perusahaan secara simultan berpengaruh pada variabel nilai perusahaan. Oleh karena itu, model persamaan regresi dalam penelitian ini layak untuk digunakan.

Tabel 10.

Hasil Uji Hipotesis (Uji t)

\begin{tabular}{clcc}
\hline Model & & T & Sig. \\
\hline 1 & (Constant) & 1,729 & 0,087 \\
& Opini Auditor & 1,848 & 0,068 \\
& Pertumbuhan Penjualan & 4,904 & 0,000 \\
\hline
\end{tabular}

Sumber: Data diolah, 2018

Berdasarkan data yang disajikan dalam tabel 10 dapat diketahui nilai $\mathrm{t}$ hitung dan tingkat signifikansi t hitung dari masing-masing variabel bebas yang digunakan dalam penelitian. Variabel opini auditor memiliki nilai t hitung sebesar 1,848 dengan tingkat signifikansi 0,068 . Nilai signifikansi t hitung untuk variabel opini auditor sebesar 0,068 lebih dari level of significant yang digunakan yaitu 0,05 . Hal ini memiliki arti bahwa opini auditor $\left(\mathrm{X}_{1}\right)$ tidak berpengaruh pada nilai perusahaan (Y) yang di proksikan dengan Tobin's Q. Hasil tersebut menunjukkan bahwa hipotesis pertama $\left(\mathrm{H}_{1}\right)$ yang menyatakan opini auditor berpengaruh positif pada nilai perusahaan ditolak.

Variabel pertumbuhan penjualan perusahaan memiliki nilai $\mathrm{t}$ hitung sebesar 4,904 dengan tingkat signifikansi 0,000. Nilai signifikansi t hitung untuk variabel pertumbuhan penjualan sebesar 0,000 kurang dari level of significant yang digunakan yaitu0,05. Hal ini memiliki arti bahwa pertumbuhan penjualan $\left(\mathrm{X}_{2}\right)$ berpengaruh positif pada nilai perusahaan $(\mathrm{Y})$ yang di proksikan dengan Tobin's Q. Hasil tersebut menunjukkan bahwa hipotesis kedua $\left(\mathrm{H}_{2}\right)$ yang menyatakan pertumbuhan penjualan perusahaan berpengaruh positif pada nilai perusahaan diterima. 
Hipotesis pertama pada penelitian ini menyatakan bahwa opini auditor berpengaruh positif pada nilai perusahaan. Berdasarkan uji parsial (uji t) menggunakan analisis regresi linier berganda diperoleh hasil bahwa t hitung bernilai positif sebesar 1,848 dengan signifikansi sebesar 0,068. Nilai signifikansi 0,068 lebih dari level of significant yang digunakan yaitu 0,05 . Hasil tersebut menunjukkan bahwa opini auditor tidak berpengaruh pada nilai perusahaan, sehingga $\mathrm{H}_{1}$ ditolak. Penolakan hipotesis tersebut memiliki makna bahwa, jenis opini yang diberikan auditor berdasarkan proses audit yang dilakukan pada laporan keuangan perusahaan tidak mempengaruhi tinggi rendahnya nilai perusahaan.

Hasil penelitian ini menunjukkan bahwa, perhatian pengguna laporan terhadap informasi perusahaan terutama terkait dengan opini audit pada laporan auditor independen masih rendah. Rendahnya perhatian pada opini audit dapat disebabkan karena pengguna atau pembaca laporan audit kurang memahami makna dan nilai yang terkandung dalam informasi yang disampaikan melalui opini auditor independen. Rendahnya perhatian tersebut juga dapat disebabkan karena opini yang dicantumkan pada laporan audit hanya digunakan sebagai informasi pendukung, bukan sebagai informasi utama dalam menentukan keputusan bisnis. Oleh karena itulah, pengguna laporan seperti pihak investor dan kreditur tidak menjadikan opini audit sebagai sinyal, dasar penilaian resiko, ataupun dasar pengambilan keputusan untuk menanamkan modal yang dimiliki pada perusahaan. 
Tidak berpengaruhnya opini audit pada nilai perusahaan juga memiliki makna bahwa investor, kreditur, ataupun pihak berkepentingan lainnya dalam mempertimbangkan keputusan bisnis masih belum sepenuhnya memaksimalkan informasi terkait opini audit yang berasal dari laporan auditor independen. Akan tetapi, pihak-pihak tersebut juga mempertimbangkan informasi tentang faktor lain yang dapat mempengaruhi nilai suatu perusahaan, misalnya kondisi tata kelola yang dimiliki oleh perusahaan dan struktur modal perusahaan. Hasil penelitian ini sesuai dengan penelitian yang dilakukan oleh Nugrahani (2018) dan Dewata (2017), yang membuktikan bahwa opini auditor tidak berpengaruh pada nilai perusahaan.

Hipotesis kedua pada penelitian ini menyatakan bahwa pertumbuhan penjualan perusahaan berpengaruh positif pada nilai perusahaan. Berdasarkan uji parsial (uji t) menggunakan analisis regresi linier berganda diperoleh hasil bahwa $t$ hitung bernilai positif sebesar 4,904 dengan signifikansi sebesar 0,000. Nilai signifikansi 0,000 kurang dari level of significant yang digunakan yaitu 0,05. Hasil tersebut memiliki arti bahwa pertumbuhan penjualan perusahaan berpengaruh positif pada nilai perusahaan, sehingga $\mathrm{H}_{2}$ diterima. Hal ini menunjukkan pertumbuhan penjualan perusahaan yang mengalami peningkatan setiap tahunnya akan menyebabkan nilai perusahaan juga mengalami peningkatan, begitupula sebaliknya.

Adanya hubungan positif antara pertumbuhan penjualan perusahaan dengan nilai perusahaan dapat mendukung teori sinyal. Teori tersebut menjelaskan bahwa perusahaan yang berkualitas baik sengaja memberikan sinyal 
berupa informasi kepada pasar. Penyampaian informasi yang dilakukan oleh perusahaan kepada pasar memiliki harapan agar pasar dapat membedakan perusahaan yang berkualitas baik dan berkualitas buruk. Informasi terkait dengan pertumbuhan penjualan perusahaan yang mengalami peningkatan merupakan suatu good news yang dimiliki perusahaan karena menjadi salah satu bukti yang dapat menunjukkan bahwa perusahaan benar-benar bertumbuh.

Pertumbuhan penjualan digunakan oleh banyak pihak baik pemilik perusahaan, calon investor, kreditur, maupun pihak lain untuk melihat prospek suatu perusahaan. Dengan melihat data penjualan dimasa lalu, perusahaan dapat mengoptimalkan sumber daya yang dimiliki untuk mengembangkan nilai perusahaan. Para investor juga dapat menggunakan data terkait dengan pertumbuhan penjualan untuk memproyeksikan keuntungan yang akan didapatkan atas modal yang diinvestasikan pada perusahaan. Bagi para kreditur, memantau pertumbuhan penjualan dilakukan sebagai salah satu bukti dari aktivitas pemanfaatan sumber daya yang dilakukan oleh perusahaan. Oleh karena itu, penjualan perusahaan yang mengalami peningkatan dan tidak diikuti dengan penambahan beban atau biaya yang besar, akan menjadi informasi penting yang menandakan bahwa aktivitas operasional perusahaan telah dilakukan dengan baik. Hal ini tentunya dapat membuka peluang investasi baru pada perusahaan, dan menyebabkan nilai perusahaan meningkat. Hasil penelitian ini sejalan dengan penelitian yang dilakukan oleh Fista (2017), Sandag (2015), serta Sharon dan Murni (2015) 
Penelitian ini menghasilkan simpulan mengenai pengaruh opini auditor dan pertumbuhan penjualan perusahaan pada nilai perusahaan manufaktur sektor barang konsumsi yang terdaftar di BEI tahun 2013 sampai dengan 2017. Secara teoritis hasil penelitian ini dapat memberikan bukti empiris yaitu opini auditor tidak memiliki pengaruh pada nilai perusahaan, sedangkan pertumbuhan penjualan perusahaan memiliki pengaruh positif pada nilai perusahaan. Hasil penelitian ini dapat digunakan sebagai referensi dan bahan pengembangan penelitian selanjutnya mengenai pengaruh opini auditor dan pertumbuhan penjualan perusahaan pada nilai perusahaan.

Hasil dari penelitian ini juga mendukung teori sinyal yang menjelaskan bahwa perusahaan yang berkualitas baik sengaja memberikan sinyal pada pasar, dengan demikian pasar diharapkan dapat membedakan perusahaan yang berkualitas baik dan yang berkualitas buruk. Informasi terkait dengan penjualan perusahan yang mengalami peningkatan dapat menjadiberita baik (good news) yang dimiliki perusahaan. Good news tersebut akan direspon positif oleh pihak yang memiliki kepentingan dengan perusahaan seperti investor dan kreditur, sehingga dapat meningkatkan nilai perusahaan.

\section{SIMPULAN}

Berdasarkan hasil analisis dan pembahasan makasimpulan dalam penelitian ini yaitu 1) opini auditor tidak berpengaruh pada nilai perusahan manufaktur sektor barang konsumsi yang terdaftar di Bursa Efek Indonesia tahun 2013-2017. 2) Pertumbuhan penjualan perusahaan berpengaruh positif pada nilai perusahan 
manufaktur sektor barang konsumsi yang terdaftar di Bursa Efek Indonesia tahun 2013-2017. Berdasarkan hasil penelitian dan simpulan, maka saran-saran yang dapat diberikan penulis adalah sebagai berikut. Nilai adjusted $\mathrm{R}^{2}$ pada penelitian ini masih tergolong rendah yaitu 0,227 atau 22,7 persen. Berdasarkan hasil tersebut maka, peneliti selanjutnya disarankan untuk mengubah atau menambah variabel lain untuk menentukan faktor-faktor yang mempengaruhi nilai perusahaan. Variabel lain yang dapat digunakan misalnya profitabilitas, kebijakan hutang, kebijakan dividen dan pengungkapan corporate social responsibility perusahaan.

Pada penelitian ini terdapat banyak perusahaan yang memiliki data outlier. Data outlier tersebut menyebabkan banyak perusahaan sampel harus dikeluarkan dari peng0amatan, yaitu 16 perusahaan. Dampak adanya data outlier adalah residual data tidak terdistribusi secara normal. Data outlier dalam penelitian ini muncul karena terdapat nilai perusahaan yang terlalu rendah dan terlalu tinggi. Hal ini dikarenakan terdapat perbedaan ukuran perusahaan yang menjadi sampel penelitian. Oleh karena itu, peneliti selanjutnya disarankan untuk menggunakan ukuran perusahaan sebagai variabel kontrol, agar penelitian yang dilakukan tidak memiliki banyak data outlier.

Bagi pihak manajemen perusahaan yang ingin meningkatkan nilai perusahaan perlu memperhatikan penjualan perusahaan. Hal ini dikarenakan faktor tersebut memiliki pengaruh positif pada nilai perusahaan. Pertumbuhan penjualan yang meningkat akan menjadi informasi baik yang dimiliki perusahaan berkaitan dengan tujuan untuk memaksimalkan nilai perusahaan. Bagi pihak 
investor dan kreditur dapat memperhatikan pertumbuhan penjualan perusahaan dalam melakukan keputusan bisnis. Hal tersebut dikarenakan pertumbuhan penjualan merupakan salah satu faktor internal perusahaan yang mampu menunjukkan bahwa perusahaan memiliki kinerja yang baik.

\section{REFERENSI}

Antwi, S., \& Mills, E. (2012). Capital Structure and Firm Value: Empirical Evidence from Ghana. Internatioanl Journal of Business and Social Sciense, 3(22), 103-111. http://ijbssnet.com/journals/Vol_3_No_22_Special_Issue_November_2012/ 10.pdf

Ardiana, P. A. (2014). The Role of External Audit in Improving Firm's Value: Case of Indonesia. In the 5th International Conference of the Japanese Accounting Review. Kobe.

Bella, G., \& Suaryana, I. G. N. A. (2017). Pengaruh IOS dan Pengungkapan CSR pada Nilai Perusahaan dengan Pertumbuhan Perusahaan sebagai Variabel Pemoderasi. E-Jurnal Akuntansi Universitas Udayana, 19 (1), 508-535.

Birjandi, H., \& Hakemi, B. (2015). The Study Effect Agency Theory and Signaling Theory on the Level of Voluntary Disclosure of Listed Companies in Tehran Stock Exchange. Research Journal of Finance and Accounting, 6(1), 174-184.

Carnevela, C. R. (2017). Pengaruh Pertumbuhan Penjualan, Ukuran Perusahaan, dan Struktur Aktiva terhadap Struktur Modal. Jurnal Ilmu Dan Riset Manajemen, 6(3), 1-17.

Chung, K. H., \& W.Pruitt, S. (1994). A Simple Approximation of Tobin's q. Financial Management, 23(3), 70-74.

Dewata, E. (2017). Pengaruh Board Size dan Kualitas Audit terhadap Nilai Perusahaan Tambang Batubara yang Terdaftar di BEI. Sinopsium Nasional Akuntansi XVIII Medan.

Farooq, S., \& Ahmed, S. (2015). Overinvestment, Growth Opportunities and Firm Performance: Evidence from Singapore Stock Market. Corporate Ownership and Control, 12(3), 454-467. 
Fista, B. F. (2017). Pengaruh Kebijakan Dividen, Pertumbuhan Penjualan, Profitabilitas dan Ukuran Perusahaan terhadap Nilai Perusahaan. Jurnal Ilmu Dan Riset Akuntansi, 6(5), 2051-2070.

Gherghina, S. C. (2015). Corporate Governance Ratings and Firm Value: Empirical Evidence from the Bucharest Stock Exchange. International Journal of Economics and Financial Issues, 5(1), 97-110.

Gill, A., \& Obradovich, J. (2012). The Impact of Corporate Governance and Financial Leverage on the Value of American Firms. International Research Journal of Finance and Economics, 1(91), 1-14.

Hansen, V., \& Huniarti. (2014). Perngaruh Family Control, Size, Sales Growth, dan Leverage terhadap Profitabilitas dan Nilai Perusahaan pada Sektor Perdagangan, Jasa, dan Investasi. Business Accounting Review, 2(1), 121130. https://doi.org/10.1017/CBO9781107415324.004

Herawaty, V. (2008). Peran Praktek Corporate Governance sebagai Moderating Variable dari Pengaruh Earnings Management terhadap Nilai Perusahaan. Jurnal Akuntansi Dan Keuangan, 10(2), 97-108. https://doi.org/10.9744/jak.10.2.pp. 97-108

Jensen, M. C., \& Meckling, W. H. (1976). Theory of the Firm: Managerial Behavior, Agency Costs and Ownership Structure. Journal of Finance Economics, 3(4), 305-360. https://doi.org/10.2139/ssrn.94043

Kurniawati, H. (2016). Pengaruh Board Size, Leverage, dan Kualitas Audit terhadap Nilai Perusahaan. Jurnal Keuangan Dan Perbankan, 12(2), 110127.

Mandalika, A. (2016). Pengaruh Struktur Aktiva, Struktur Modal dan Pertumbuhan Penjualan terhadap Nilai Perusahaan pada Perusahaan Publik yang Terdaftar di Bursa Efek Indonesia (Studi pada Sektor Otomotif). Jurnal Berkala Ilmiah Efisiensi, 16(01), 207-218.

Martinez, A. L. (2014). Association Between Independent Auditor Fees and Firm Value: a Study of Brazilian Public Companies. Journal of Modern Accounting and Auditing, 10(4), 442-450.

Moazedi, E., \& Khansalar, E. (2016). Earnings Management and Audit Opinion. International Journal of Economics and Finance, 8(4), 113-122. https://doi.org/10.5539/ijef.v8n4p113

Nugrahani, S. (2018). Pengaruh Opini Audit terhadap Harga Saham dengan Ukuran Kantor Akuntan Publik sebagai Variabel Pemoderasi. Jurnal Akuntansi, 5(1), 74-86. 
Pakdaman, H. (2018). Auditor's Opinion and Market Reaction of Companies Listed on the Tehran Stock Exchange (TSE). Revista Publicando, 5(14), 101-118.

Purbawati, D. (2016). Pengaruh Opini Audit dan Luas Pengungkapan Sukarela terhadap Perubahan Harga Saham. Jurnal Administrasi Bisnis, 5(1), 6-12.

Purwohandoko. (2017). The Influence of Firm's Size, Growth, and Profitability on Firm Value with Capital Structure as the Mediator: A Study on the Agricultural Firms Listed in the Indonesian Stock Exchange. International Journal of Economics and Finance, 9(8), 103-110. https://doi.org/10.5539/ijef.v9n8p103

Putri, S. U., \& Dwija, I. G. . M. A. (2016). Opini Auditor spurwoebagai Pemoderasi Pengaruh Good Corporate Governance pada Nilai Perusahaan. E-Jurnal Akuntansi Universitas Udayana, 17(1), 29-55.

Rasyid, A. (2015). Effects of Ownership Structure, Capital Structure, Profitability and Company's Growth Towards Firm Value. International Journal of Business and Management Invention, 4(4), 25-31.

Sandag, N. J. (2015). Pertumbuhan Penjualan, Ukuran Perusahaan, Return on Asset dan Struktur Modal terhadap Nilai Perusahaan pada Perusahaan yang Tercatat pada Indeks LQ 45. Jurnal Riset Bisnis Dan Manajemen, 3(3), 214225.

Sharon, M., \& Murni, S. (2015). Analisa Pertumbuhan Penjualan, Ukuran Perusahaan, Return on Asset, dan Struktur Modal terhadap Nilai Perusahaan yang Tercatat di Indeks Lq 45. Jurnal EMBA, 3(1), 961-971

Spence, M. (1973). Job Market Signaling. The Quarterly Journal of Economics, 87(3), 355-374. https://doi.org/10.2307/1882010

Suffah, R., \& Riduwan, A. (2016). Pengaruh Profitabilitas, Leverage, Ukuran Perusahaan dan Kebijakan Dividen pada Nilai Perusahaan. Jurnal Ilmu Dan Riset Akuntansi, 5(2), 1-17.

Susianti, Maria., \& Yasa, G. W. (2013). Pengaruh Kinerja Keuangan terhadap Nilai Perusahaan dengan Pemoderasi Good Corporate Governance dan Corporate Social Responsibility. E-Jurnal Akuntansi Universitas Udayana, 3(1), 73-91.

Wulandari, A. A., \& Ramantha, I. W. (2016). Dampak Moderasi Profitabilitas terhadap Pengaruh Corporate Social Responsibility pada Nilai Perusahaan Manufaktur. E-Jurnal Ekonomi Dan Bisnis Universitas Udayana, 5(7), 1889-1918. 